DOI: $10.2478 / \mathrm{v} 10014-012-0015-2$

Agrovoc descriptors: solanum tuberosum, potatoes, root vegetables, sprayers, nozzles, application methods, chemical control, control methods, fungicides, plant protection, disease control, equipment, plant protection equipment, equipment, equipment parts

Agris category code: h20, n20

\title{
Improved quality of fungicide deposition and coverage of potato leaves using flat fan air-injector nozzle IDK
}

\author{
Filip VUČAJNK ${ }^{1}$, Rajko BERNIK ${ }^{2}$
}

Received January 16, 2012; accepted February 20, 2012.

Delo je prispelo 16. januarja 2012, sprejeto 20. februarja 2012.

\begin{abstract}
The aim of our experiment was to improve fungicide spray deposition and coverage of potato leaves by using air-injector nozzle types. We used two standard nozzle types - a flat fan nozzle ST and a hollow cone nozzle TR, as well as a couple of air-injector nozzle types - an air-injector compact nozzle IDK and a symmetric double flat fan air-injector nozzle TWIN (with a $30^{\circ}$ forward and a $30^{\circ}$ backward spray jet angle). Water-sensitive paper was placed on the upper, middle and lower part of the plant in order to determine the quality of fungicide deposition and the ability of droplets to penetrate lower parts of the plant. When using the air-injector compact nozzle IDK, potato leaves were covered well at all three levels of the plant. The use of the above-mentioned nozzle resulted in the lowest reduction in coverage value and droplet impression area from the top towards the lowest part of the plant. Furthermore, the nozzle created large enough droplets with sufficient mass and speed to penetrate the dense canopy all the way to the lowest part of the plant. When using the symmetric double flat fan air-injector nozzle TWIN, the angle of both spray jets was excessively wide in order for the droplets to reach the lower part of the plant despite a very large droplet impression area. The use of both standard nozzle types resulted in a poor spray mixture coverage of the middle and lower part of the plant. This predominantly occurred due to insufficient droplet size and the subsequent lack of kinetic energy. Results show that the use of a newer air-injector compact nozzle IDK improves the deposition and coverage of potato leaves with spray mixture.
\end{abstract}

Key words: deposition, coverage, nozzles, potato, fungicide

\section{IZVLEČEK}

\section{IZBOLJŠANJE DEPOZICIJE IN POKRITOSTI LISTOV KROMPIRJA S ŠKROPILNO BROZGO PRI UPORABI INJEKTORSKE ŠPRANJASTE ŠOBE IDK}

Namen poskusa je bil izboljšanje nanosa in pokritosti listov krompirja s škropilno brozgo pri uporabi novejših izvedb injektorskih šob. Uporabili smo dve standardni izvedbi šob, špranjasto šobo ST in vrtinčno šobo TR ter dve injektorski izvedbi šob, šobo IDK in šobo z dvojnim simetričnim curkom TWIN (škropilni curek pod kotom $30^{\circ}$ naprej in $30^{\circ}$ nazaj). $\mathrm{Na}$ zgornji, srednji in spodnji del rastline smo namestili na vodo občutljive lističe, da bi pri uporabljenih šobah ugotovili kakovost fungicidnega nanosa in sposobnost prodiranja kapljic v spodnje dele rastlin. Ugotovili smo, da je bila najboljša pokritost listov krompirja na vseh etažah pri uporabi injektorske šobe IDK. Pri tej šobi je bilo najmanjše zmanjšanje odstotka pokritosti in površine odtisa posamezne kapljice od vrha proti spodnjemu delu rastline. Ta šoba tvori dovolj velike kapljice, ki imajo veliko hitrost in zadostno maso, da lahko prodrejo skozi gost listni sestoj do spodnjega dela rastline. Pri injektorski šobi $\mathrm{z}$ dvojnim simetričnim curkom TWIN je bil kot obeh škropilnih curkov prevelik, da bi kapljice zadele spodnji del rastline, kljub temu da je bila površina odtisa posamezne kapljice zelo velika. Pri obeh standardnih izvedbah šob je bila preslaba pokritost s škropilno brozgo v srednjem in spodnjem delu rastline predvsem zaradi premajhnih kapljic in posledično premajhne kinetične energije. Rezultati kažejo izboljšanje depozicije in pokritosti listov krompirja s škropilno brozgo pri uporabi novejše injektorske šobe IDK.

Ključne besede: nanos, pokritost, šobe, krompir, fungicid

\footnotetext{
1 Ph.D., University of Ljubljana, Biotechnical Faculty, Department of Agronomy, Jamnikarjeva 101, SI-1111 Ljubljana, e-mail: filip.vucajnk@bf.uni-lj.si

2 Prof., Ph.D., Biotechnical Faculty, Department of Agronomy, Jamnikarjeva 101, SI-1111 Ljubljana
} 


\section{INTRODUCTION}

Spray deposition on the target surface proved to be the decisive factor in spraying with plant protection products (PPP). It is possible to affect the quality of spray deposition on the target surface by changing droplet size, volume application rate, pressure and driving speed. Fine droplets can provide better fungicide coverage, however, with a lesseffective droplet penetration through the canopy (Stangl, 2009). Required volume application rate and adequate fungicide deposition rate result in a good spray coating on the target surface and represent the basic requirement for an effective disease control. Lower volume application rate results in a smaller number of droplets and a smaller spray coating on the target surface (Brune, 2011).

Potato has a different morphology than other cultivated plants. Its leaf-area index (LAI) is 4 and it has a complex system of intertwined stems and leaves at different levels which proves to be problematic for the penetration of fungicides through the canopy. Spray deposit should equally cover all parts of the plant in the highest possible degree. Potato has villous leaves and stems with cuticles enabling a quality fungicide deposition. Potato epidermis, on the other hand, does not have an extra epicuticular wax layer, characteristic of some other plants, such as oilseed rape, cabbage etc. (Strasburger, 1991). When spray droplets touch the leaf surface, they stick to it and finally rearrange throughout the surface. There is no risk of droplets bouncing off the leaves or trickling away (Luckhard and Brune, 2011).

In the potato late blight control, timely spraying and high-quality fungicide deposition are of extreme importance. The chemical control should involve nozzles with medium droplet size (VMD 250-350 $\mu \mathrm{m}$ ). Nozzles with a spray jet at a certain angle from the vertical allow a better leaf coverage, particularly during the main stem elongation and all the way to the point where plants meet between the rows (BBCH 301-309) (Spray Application Technique, 2003).

Nowadays, new spraying techniques are being introduced and tested in the potato late blight control. These involve reduced volume application rate (less than $50 \mathrm{l} / \mathrm{ha}$ ) in Danfoil sprayers, use of standard nozzles on airassisted sprayers, under leaf fungicide deposition and use of nozzles with different spray jets on classic sprayers (Kryger Jensen, 2007).

Several authors determined the effect of various nozzle types on the coverage of potato leaves with fungicides. According to Kierzek and Wachowiak (2009), the best coverage of potato leaves can be achieved by using driftreducing nozzles and double flat fan nozzles. On the lower part of the plant, coverage of the upper part of the leaves was 3 to 5 times better than on the lower part of the leaves. Furthermore, Kierzek and Wachowiak (2007) determined the highest spray deposit and the best coverage of potato plant with the use of a special flat fan nozzle with a spray jet revolved backwards at a $30^{\circ}$ angle from the vertical. An air-assisted sprayer was used in the trial. Airinjector flat fan nozzle with a single spray jet and standard flat fan nozzle were both less effective in the coverage of potato leaves.

Kryger Jensen (2007) stated a similar biological efficacy of air-injector nozzles in comparison with standard and drift-reducing nozzles. Backward angled nozzles proved to reach a better coverage of potato leaves than nozzles with a vertical spray jet. At times, airassisted sprayers prove to be more biologically effective. With Danfoil sprayers, smaller volume application and fungicide deposition rates may be used. This could, however, result in reduced biological efficacy. Under-leaf deposition of spray mixture may improve the efficacy but it would simultaneously reduce 
the area efficiency and raise the expenses (Kryger Jensen, 2007).

According to Klausen (2007), air-injector nozzles proved to be more effective in the coverage of potato leaves in comparison with standard nozzles. The coverage on the upper part of the plant was better when air-assisted sprayers and Danfoil sprayers had been used. The use of Danfoil sprayers resulted in the best coverage of the middle part of the plant. With a reduced volume application rate $(1201 / \mathrm{ha})$, the largest coverage was reached by airassisted sprayers and Danfoil sprayers.

Kierzek (2007) compared the fungicide deposition quality on potato plants between a standard nozzle with a vertical spray jet and a nozzle with a $45^{\circ}$ spray jet. In comparison with the standard nozzle, the latter reached an approximately $50 \%$ better coverage of the upper part of the leaves. Coverage of the lower part of the leaves with the nozzle having a $45^{\circ}$ spray jet was 3-5 times better.

Gajtkowski et al. (2005) determined that, in comparison with air-injector nozzles, the use of standard nozzles results in a better coverage of potato leaves. With the pressure raised from 2 to 4 bars, the number of droplets per $\mathrm{cm}^{2}$ when air-injector nozzles had been used was reduced under the allowed limit (20 droplet impressions per $\mathrm{cm}^{2}$ ).

Stallinga et al. (2010) wanted to determine the effect of driving speed and various nozzle types on spray deposition quality and biological efficacy of Shirlan fungicide (AI fluazinam) in potato late blight control. At the referential $100 \%$ application rate, there were no statistically significant differences. They did, however, occur with smaller fungicide and volume application rates (65 and 135 1/ha respectively). Standard nozzles reached better results than air-injector nozzles. An increase of the driving speed from 2 to $4 \mathrm{~m} / \mathrm{s}$ reduced biological efficacy of the fungicide used at the referential $100 \%$ application rate. Furthermore, droplet impression number per $\mathrm{cm}^{2}$ dropped by $40-75 \%$. Authors discovered that the droplet impression number per $\mathrm{cm}^{2}$ lower than 120 reduces biological efficacy. Coverage value and droplet impression number per $\mathrm{cm}^{2}$ were reduced, from the top towards the lower part of the plant.

Knewitz and Koch (2010) established that, in comparison with single spray jet air-injector nozzles, the use of symmetric double flat fan air-injector nozzles resulted in a better coverage of potato plant. The coverage reached by using the asymmetric double flat fan air-injector nozzle was, however, slightly smaller than with other air-injector nozzle types.

Luckhard and Brune (2011) confirmed a much better spray deposition on the upper two thirds of the plant in comparison with the lower third of the plant, regardless of the nozzle type. In comparison with other air-injector nozzle types, the use of symmetric double compact air-injector nozzles resulted in a better coverage of potato plant. Asymmetric and symmetric double flat fan air-injector nozzles reached better coverage values than single spray jet air-injector nozzles. Due to a smaller number of droplets, the coverage of potato plant at a $1501 /$ ha volume application rate was much smaller than at $3501 /$ ha. Due to a smaller number of coarse droplets, droplet impression mass on the upper third of the plant was relatively high, whereas the coverage value was small. Despite the extremely coarse $(450-575 \mu \mathrm{m})$ and coarse $(350-450 \mu \mathrm{m})$ volume median diameter (VMD) of droplets formed by nozzles, spray deposition on the leaves was good due to a special leaf surface structure of potato plant. Fungicide deposition quality proved to be better at a $3501 /$ ha than at a $150 \mathrm{l} / \mathrm{h}$ volume application rate.

The aim of the trial was to determine the spray deposition quality on potato leaves according to various nozzle types. Furthermore, we wanted to research the coverage of potato 
leaves with spray mixture on the lower part of the plant and to determine which nozzle type is the most suitable one for penetrating the thick canopy, from the top towards the lower part of the plant. Two standard nozzle types were used in the trial, namely a flat fan nozzle ST and a hollow cone nozzle TR. We also included two newer nozzle types - a single spray jet air-injector compact nozzle IDK and a symmetric double flat fan air-injector nozzle AVI-TWIN. In Slovenia, it is customary to use standard nozzles. Air-injector nozzles, on the other hand, are used less frequently. We were interested in finding out whether the new nozzle types ensure a better spray deposition on potato leaves in comparison with standard nozzles. We put forth a hypothesis that, particularly in the middle and lower part of the plant, the use of the two air-injector nozzle types ensures a better spray deposition in comparison with the two standard nozzle types. Moreover, we presumed that both airinjector nozzle types are able to penetrate the canopy better than the standard nozzle types.

\section{MATERIALS AND METHODS}

4 different nozzle types - 2 standard ones and 2 air-injector ones - were used in the potato spraying trial (Figure 1). Among the standard nozzle types, there were a standard flat fan nozzle ST 110-03 and a standard hollow cone nozzle TR 80-03 C, while air-injector nozzle types included a flat fan air-injector nozzle IDK 120-03 C and a symmetric double flat fan air-injector nozzle AVI TWIN 110 03. The latter had a $30^{\circ}$ forward and a $30^{\circ}$ backward spray jet in accordance with the spraying direction.

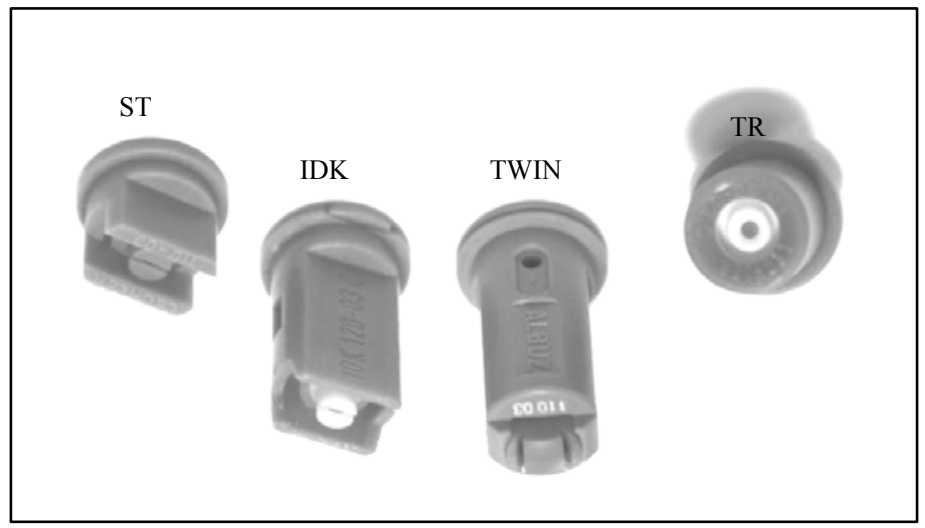

Figure 1: Nozzles used in the trial

The trial was performed on lighter soil, in Dol pri Ljubljani, in the year 2009. The trial was based on 3 random blocks with 3 repetitions within trial units. Each of three block was $12 \mathrm{~m}$ wide and $5 \mathrm{~m}$ long. $10 \mathrm{~m}$ divider strips were created among the blocks. Within each block, various nozzle types were randomly distributed along the spray boom. Nozzles of the same type were placed together in groups of 4 or 5 , it means 2 to $2.5 \mathrm{~m}$ wide. In the trial, a medium-to-late Aladin potato cultivar was used at a $75 \mathrm{~cm}$ inter row width. Potatoes were planted at a distance of $29.6 \mathrm{~cm}$, creating an exact tuber density of $45,000 /$ ha.

During the inflorescence emergence, when approximately $40 \%$ of flowers were already open (BBCH 604), potato was sprayed with systemic and contact fungicide Melody Duo (AI iprovalicarb and propineb) at a $2.5 \mathrm{~kg} / \mathrm{ha}$ application rate. This fungicide is used in potato late blight (Phytophthora infestans) and 
early blight (Alternaria solani) control during the period of intensive growth. During the spraying, plants were $70 \mathrm{~cm}$ high. Each treatment involved three randomly selected plants in the same row. The chosen plants were always located in the middle, on the spot corresponding to the third nozzle (out of five) of each nozzle type. We thus managed to avoid the edge effect of spray jets from the adjacent nozzle types on our measuring place. We attached water-sensitive paper to the upper leaf surface in the upper $(70 \mathrm{~cm}$ from the ground), middle ( $40 \mathrm{~cm}$ from the ground) and lower part $(10 \mathrm{~cm}$ from the ground) of the plant (Figure 2). This was done with the aid of paperclips. There was approx. $30 \mathrm{~cm}$ of vertical distance among various measuring papers. Measuring papers were $76 \mathrm{~mm}$ long and $26 \mathrm{~mm}$ wide. Each treatment involved 9 measuring papers. Due to a possible effect of tractor/sprayer passage on the spray deposition on measuring papers, measurements were not performed along the tramlines. Tractor mounted sprayer with a 6001 tank capacity and a $12 \mathrm{~m}$ wide spray boom was used in the trial (Figure 3). Spray boom was located $50 \mathrm{~cm}$ from the target surface. Driving speed during the spraying was $4.1 \mathrm{~km} / \mathrm{h}$ and working pressure amounted to 4.0 bars. There was a $4001 /$ ha volume application rate. Volume median diameter (VMD) of droplets for each nozzle type is shown in Table 1. Air temperature during the spraying was $15^{\circ} \mathrm{C}$, with a $67 \%$ relative air humidity and a $0.8 \mathrm{~m} / \mathrm{s}$ wind speed. After the spraying, measuring papers were collected and analysed.

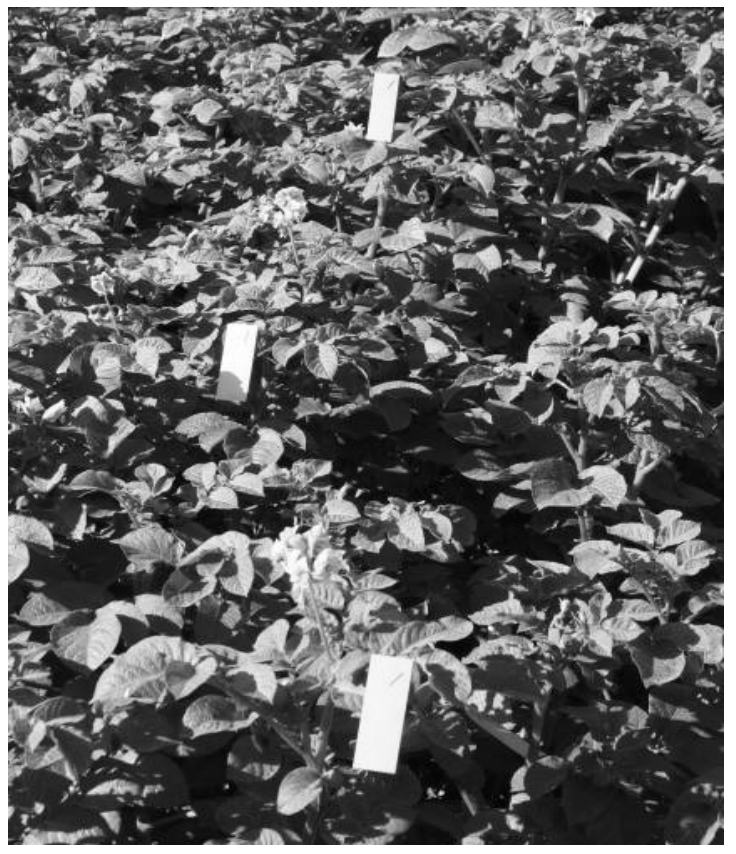

Figure 2: Water-sensitive paper on the upper parts of plants 


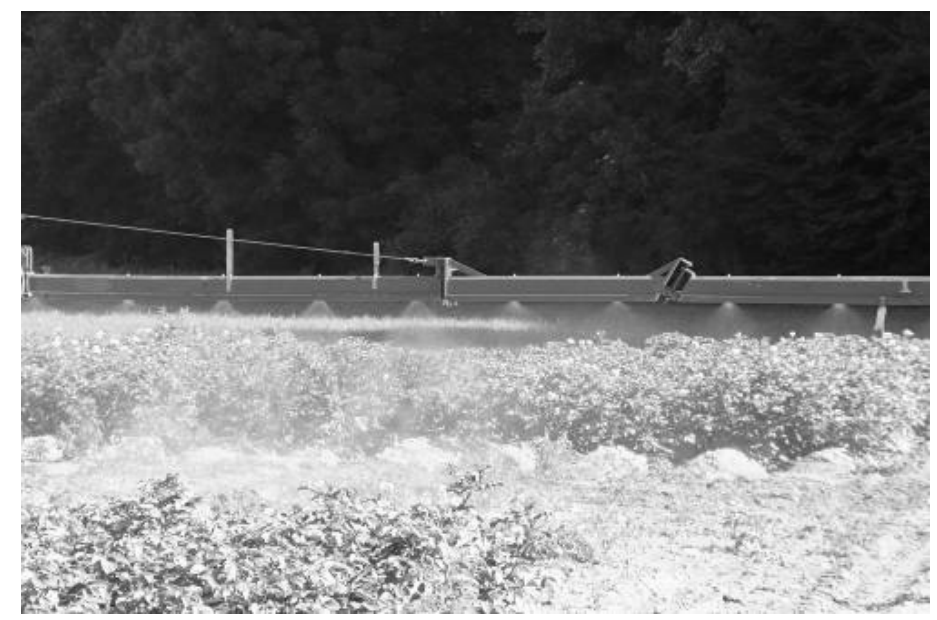

Figure 3: Spraying the field trial with tractor mounted sprayer

Table 1: VMD of droplets and droplet distribution according to BCPC and ASAE for each nozzle used in the trial, the pressure of 4.0 bars was used in all cases

\begin{tabular}{|l|r|l|}
\hline \multicolumn{1}{|c|}{ Nozzle type } & VMD $(\mu \mathrm{m})$ & Droplet distribution according to BCPC and ASAE \\
\hline ST 110-03 & 200 & fine \\
\hline IDK 120-03 C & 380 & coarse \\
\hline AVI-TWIN 110-03 & 410 & coarse \\
\hline TR 80-03 C & 100 & very fine \\
\hline
\end{tabular}

Droplet impressions on measuring papers were analysed with Optomax Image Analyser. Three measurements were performed on each measuring paper. In the APA 2001 V5.1 program, we calculated the coverage value and the droplet impression number per $\mathrm{cm}^{2}$. Based on this data, impression area of a single droplet was calculated as a quotient of coverage value and droplet impression number per $\mathrm{cm}^{2}$. In addition, relative reductions in coverage value and impression area of a single droplet, from the top towards the lowest part of the plant, were analysed. Coverage value and impression area of a single droplet on the upper part of the plant meant $100 \%$.

Statistical analysis was performed according to the procedure valid for random blocks with repetitions within the trial units (Košmelj,
2001; Hadživuković, 1991). We initially examined homogeneity of variance, using Hartley's test. Coverage value data, relative reduction in coverage value and relative reduction in impression area of a single droplet were then transformed with the asin (sqrt) function. Analysis of variance and Duncan's Multiple Range Test were performed at $\alpha=$ 0.05 . A separate analysis of the upper, middle and lower part of the plant was performed. It was followed by a joint analysis of separate parts of the plant. This gave us a more accurate picture on the spray deposition on the target surface according to individual nozzle types. If present, statistically significant differences among various treatments were marked with different letters. All statistical analyses were performed by the Statgraph 4.0 program (Statistical Graphics Corp., Manugistics, Inc.). 


\section{RESULTS AND DISCUSSION}

In comparison with the symmetric double flat fan air-injector nozzle TWIN (37\%), the standard hollow cone nozzle TR reached better coverage value $(47 \%)$ on the upper part of the plant (Figure 4). It is presumed that the slightly higher coverage value of the standard hollow cone nozzle TR was the result of a higher droplet impression number per $\mathrm{cm}^{2}$ (65) when compared with both air-injector nozzle types, namely IDK and TWIN (with 40 and 42 droplet impressions respectively). Compared to the TR nozzle, the IDK nozzle forms a smaller number of droplets, which are, however, coarser, causing the lack of statistically significant differences in the coverage value. TR nozzle forms a larger number of very fine droplets with the volume median diameter of $100 \mu \mathrm{m}$. Results of the impression area of a single droplet amounting to $0.72 \mathrm{~mm}^{2}$ partially prove that fact (Figure 6). Volume median diameter of the symmetric double flat fan air-injector nozzle TWIN was probably excessive (approx. $410 \mu \mathrm{m}$ ), causing the coverage value of this nozzle to be slightly lower. Higher pressure values and a slightly higher number of droplets per $\mathrm{cm}^{2}$ would raise the coverage value resulting from the use of this nozzle. According to nozzle producer Agrotop (2010), TWIN nozzles allow a better spray deposition on the vertically positioned plant parts in comparison with the horizontal parts, i.e. leaves on the upper part of the plant, which might be the cause of a slightly worse coverage value. Gajtkowski et al. (2005) stated that good fungicide deposition onto potato plants should involve at least 50 droplet impressions per $\mathrm{cm}^{2}$ and a coverage value higher than $15 \%$. In our trial, both air-injector nozzle types proved to deposit less than 50 droplets per $\mathrm{cm}^{2}$. On the other hand, the coverage value they reached largely exceeded the above-mentioned $15 \%$. Due to this fact, the quality of spray deposition was very high with air-injector nozzles as well. Results of coverage value indicate a very good quality of fungicide deposition on the upper part of the plant with all nozzle types used in the trial. This was concluded due to the fact that the upper part of the plant does not impede the droplets to reach the target surface. Moreover, its leaves are well exposed to the spray deposition. Our results partially correspond to the results of Gajtkowski et al. (2005), who stated that, in comparison with air-injector nozzles, the use of standard nozzles results in a better coverage of potato leaves. In our trial, this held true merely for the standard hollow cone nozzle TR in the upper part of the plant.

In the middle part of the plant, the single spray jet air-injector compact nozzle IDK reached a significantly higher coverage value (31\%) than standard ST and TR nozzles (with 22 and 20\% respectively). (Figure 4). Due to a larger volume median diameter, IDK nozzles seem to be more efficient in the penetration through the canopy, whereas the droplets formed by standard ST and TR nozzles are too small and do not have enough speed and kinetic energy to penetrate deeper into the lower parts of the plant. These results partially correspond to Klausen's findings (2007). The latter proved that the use of air-injector nozzles results in a better coverage of potato plant in comparison with the use of standard nozzles. In our trial, this held true for the middle part of the plant, and not the upper one. As anticipated, in the middle part of the plant, both ST and TR standard nozzle types proved to have a higher droplet impression number per $\mathrm{cm}^{2}$ than the IDK and TWIN air-injector nozzles (Figure 5). Nevertheless, the droplets formed by both ST and TR standard nozzles were much smaller than those of the IDK and TWIN air-injector nozzles. This was, furthermore, proved by the results of the impression area of a single droplet. With both IDK and TWIN air-injector nozzles, the impression area of a single droplet proved to be bigger $\left(0.45\right.$ and $0.60 \mathrm{~mm}^{2}$ respectively) than with the $\mathrm{ST}$ and $\mathrm{TR}$ 
standard nozzles $\left(0.21\right.$ and $0.18 \mathrm{~mm}^{2}$ respectively) (Figure 6). When comparing the two air-injector nozzles, the single spray jet IDK nozzle proved to reach a higher droplet impression number per $\mathrm{cm}^{2}$ (68) than the symmetric double flat fan nozzle TWIN (42). It is thus possible to conclude that both spray jets of the TWIN nozzle have an excessive forward and backward angle which disabled them from sending the droplets deeper into the canopy. In comparison with the upper part of the plant, the middle part had a lower coverage value regardless of the nozzle type. This was anticipated as leaves present a physical obstacle in droplet penetration to the lowerlying parts of the plant. The velocity of fine standard nozzle droplets is lower, causing them to stop earlier on their way in comparison with coarser air-injector nozzle droplets. The latter have a bigger mass, a greater velocity and, therefore, a larger kinetic energy. This is why they are able to penetrate the lower-lying parts of the plant. The increase of the vertical distance between the nozzle and the target surface resulted in a higher droplet impression number per $\mathrm{cm}^{2}$. It can be assumed this occurred due to a bigger overlap of spray patterns from the adjacent nozzles and finer droplets.

In comparison with the upper and middle part, the lower part of the plant reached the lowest coverage value with all nozzle types (Figure 4). In this aspect, the results correspond to the Luckhard and Brune's results (2011). The authors determined that, on the upper two thirds of the plant, the quality of spray deposition is much higher than on the lower third of the plant regardless of the nozzle type used. Similar to the middle part of the plant, the use of the single spray jet air-injector compact nozzle IDK resulted in a better coverage value $(23 \%)$ of the lower part of the plant in comparison with other nozzle types (16-18\%). Reasons for a quality spray deposition on the lower part of the plant by the IDK nozzle are identical to those for the middle part of the plant. The nozzle has a single vertical spray jet of coarse droplets at a high velocity, which are able to penetrate all the way to the lowest parts of the plant. The ST, TR and TWIN nozzles all reached coverage values which were only slightly higher than $15 \%$. According to Gajtkowski et al. (2005), that is the lower limit for a quality fungicide application onto potato plants. Moreover, with the majority of nozzle types, the droplet impression number per $\mathrm{cm}^{2}$ was higher on the lower part of the plant than on the middle part of the plant (Figure 5). As already mentioned, this is connected with the increase of distance between the target surface and the nozzle which causes an even bigger overlap of spray patterns from the adjacent nozzles and the reduction in droplet size. With all nozzle types, impression area of a single droplet was smaller on the leaves of the lower part of the plant than in its middle (Figure 6). However, the impression area of a single droplet reached with both IDK and TWIN airinjector nozzle types $\left(0.27\right.$ and $0.28 \mathrm{~mm}^{2}$ respectively) was statistically higher than with both ST and TR standard nozzles (0.16 and $0.13 \mathrm{~mm}^{2}$ respectively). 


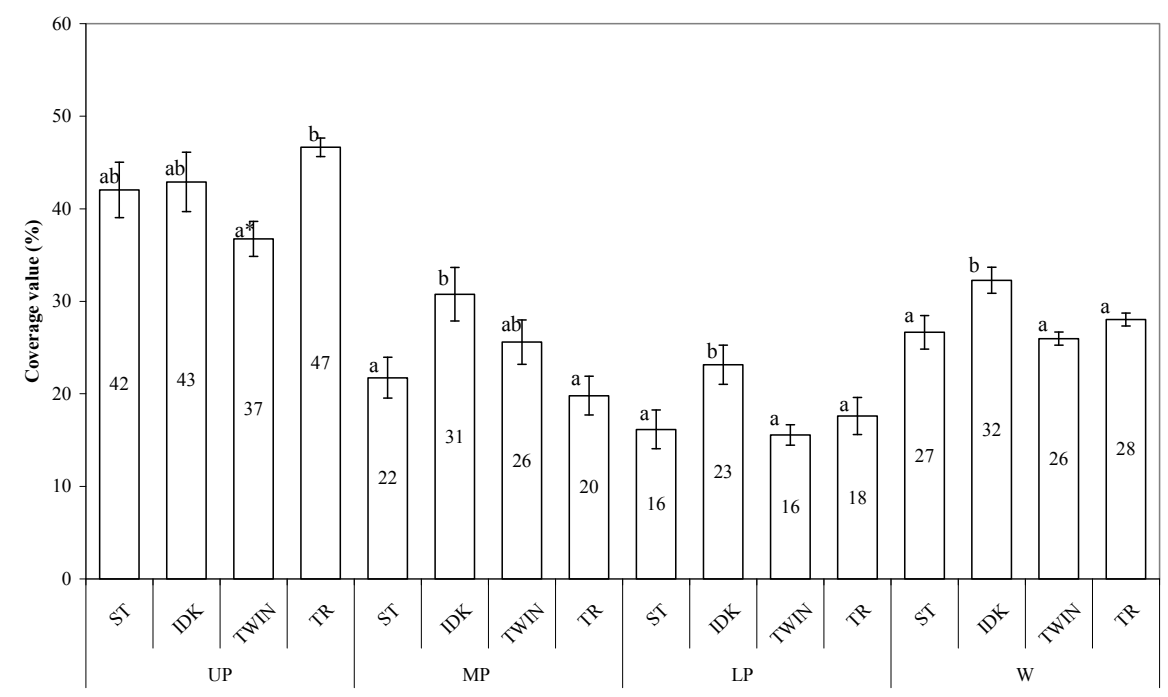

Figure 4: Coverage value on the upper, middle and lower part of the plant and on the whole plant according to the nozzle type; UP - upper part of the plant; MP - middle part of the plant; LP - lower part of the plant; W the whole plant; * means, at the same part of the plant, followed by different letters are significantly different $(p<0.05)$; bars represent standard errors.

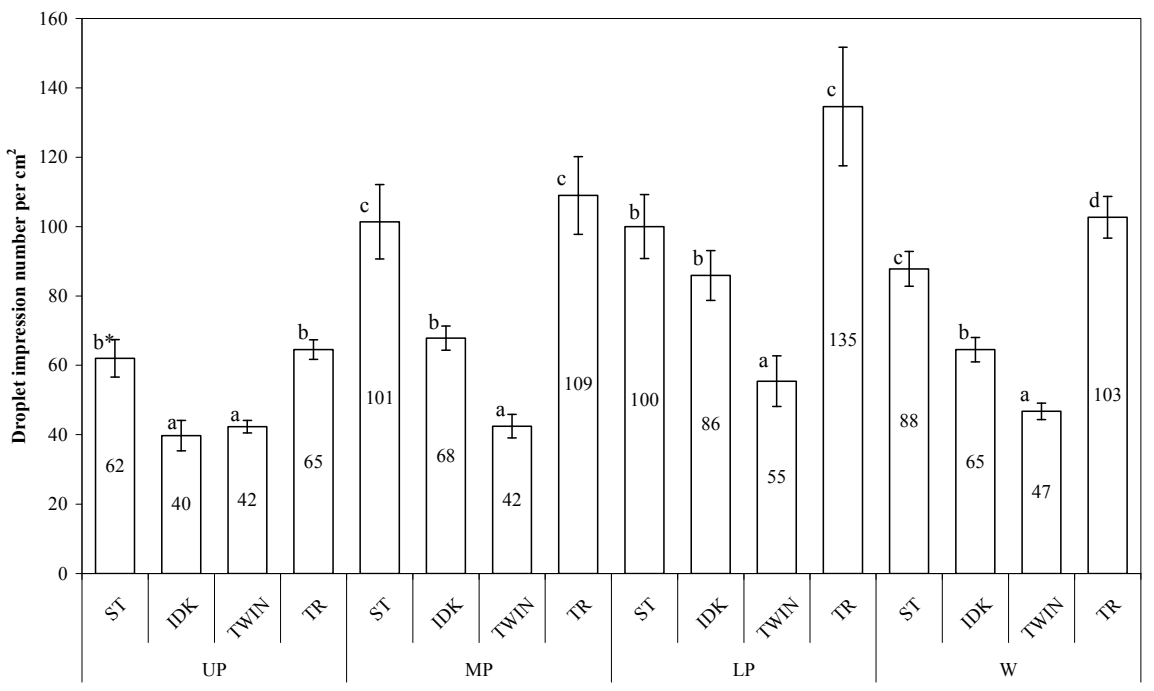

Figure 5: Droplet impression number on the upper, middle and lower part of the plant and on the whole plant according to the nozzle type; UP - upper part of the plant; MP - middle part of the plant; LP - lower part of the plant; $\mathrm{W}$ - the whole plant; * means, at the same part of the plant, followed by different letters are significantly different $(p<0.05)$; bars represent standard errors. 


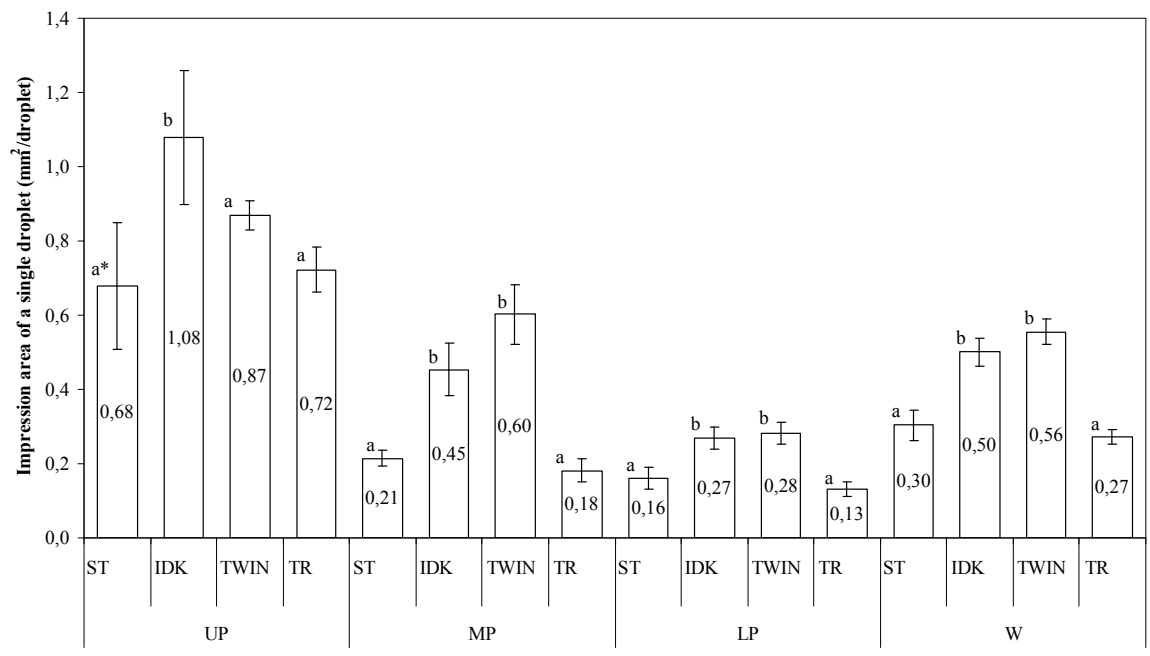

Figure 6: Impression area of a single droplet on the upper, middle and lower part of the plant and on the whole plant according to the nozzle type; UP - upper part of the plant; MP - middle part of the plant; LP - lower part of the plant; $\mathrm{W}$ - the whole plant; * means, at the same part of the plant, followed by different letters are significantly different $(p<0.05)$; bars represent standard errors.

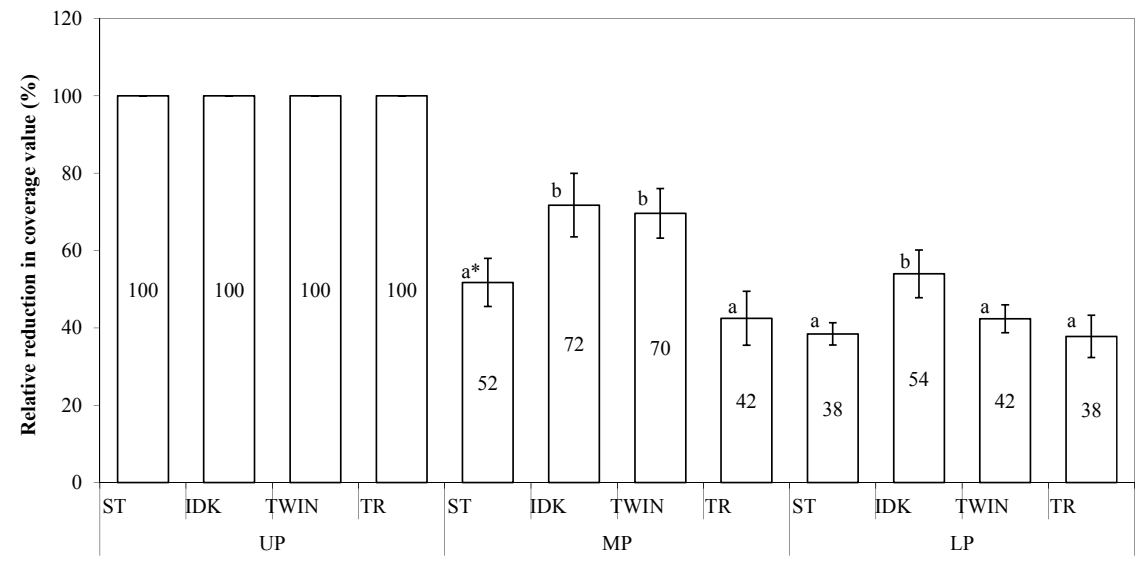

Figure 7: Relative reduction in coverage value on the middle and lower part of the plant in comparison with the upper part of the plant according to the nozzle type; UP - upper part of the plant; MP - middle part of the plant; LP - lower part of the plant; W - the whole plant; * means, at the same part of the plant, followed by different letters are significantly different $(p<0.05)$; bars represent standard errors. 


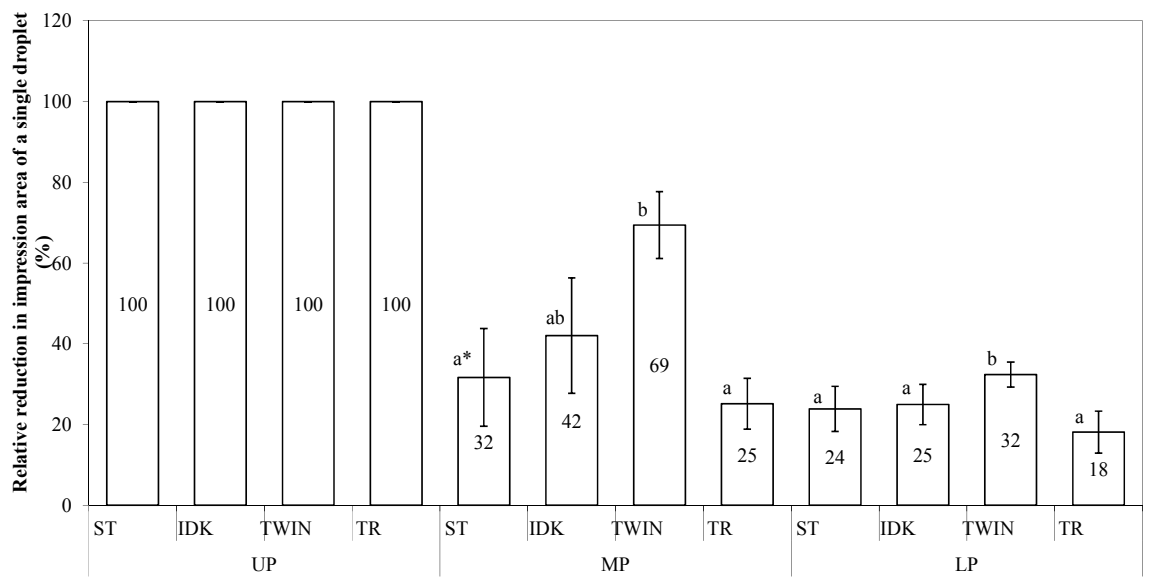

Figure 8: Relative reduction in impression area of a single droplet on the middle and lower part of the plant in comparison with the upper part of the plant according to the nozzle type; UP - upper part of the plant; MP - middle part of the plant; LP - lower part of the plant; W - the whole plant; * means, at the same part of the plant, followed by different letters are significantly different $(p<0.05)$; bars represent standard errors.

In comparison with the upper part of the plant $(100 \%)$, the use of IDK and TWIN air-injector nozzle types reduced the coverage value on the middle part to 72 and $70 \%$ respectively (Figure 7). A much bigger reduction occurred with the two standard nozzle types. The ST nozzle reduced the coverage value to $52 \%$, while the reduction of the TR nozzle amounted to $42 \%$. The reduction in coverage value on the lower part of the plant was even more distinctive than on the upper part. Once again, the use of standard ST and TR nozzles resulted in a higher reduction $(38 \%$ of value in comparison with the upper part) than the two air-injector nozzle types - IDK and TWIN (with a 54 and $42 \%$ reduction in comparison with the upper part). The above-cited results show that, predominantly with the air-injector nozzle IDK, the coverage value drops throughout the whole plant height downwards by slightly less than $50 \%$. Based on this it is possible to conclude that, when this nozzle is used, a sufficient number of droplets penetrate all the way to the lower part of the plant in order to cover a sufficiently large area. With other nozzle types, particularly the standard ST and TR nozzles, the coverage value is reduced by slightly less than $66 \%$. When comparing the relative reduction in impression area of a single droplet, from the upper towards the lower part of the plant, the relative reduction was the lowest both in the middle part (reduced to $69 \%$ of the upper part value) and the lower part of the plant by the TWIN nozzle (reduced to $32 \%$ of the upper part value) (Figure 8). Among other nozzle types (ST, IDK and TR), relative reduction in the impression area of a single droplet on the middle and lower part of the plant proved to be bigger than with the TWIN nozzle. There were, however, no statistically significant differences among the three above-stated nozzle types. Based on we concluded that thick canopy represents a great obstacle for the droplets on their way downwards. Furthermore, the impression area of a single droplet on the lower part of the plant is reduced to $1 / 3$ or $1 / 4$ of the upper part value. Impression area of a single droplet is, moreover, dependent upon the vertical distance between the nozzle and the target area. In comparison with the upper part, middle and lower parts of the plant were reached predominantly by a range of finer droplets. It is important to ensure that the difference in the size of droplets falling on the top of the plant and those reaching its lower part is not excessive. With both standard 
nozzle types (ST and TR), impression area of a single droplet was very small already in the middle, but even more in the lower part of the plant. These two nozzles form a range of fine and very fine droplets extremely sensitive to drift. Droplets are considered driftable if their volume median diameter (VMD) is smaller than $150 \mu \mathrm{m}$. According to Lešnik (2007), the nozzles which form very fine droplets (e.g. the TR nozzle) create $50-60 \%$ of driftable droplets. Nozzles forming fine droplets (e.g. the ST nozzle) have 20 to $50 \%$ driftable droplets.

On the whole, flat fan air-injector nozzle IDK proved to have the best fungicide deposition quality on potato leaves at all the levels (upper, middle and lower part of the plant). This nozzle reached the highest coverage value in the middle and lower part of the plant. A sufficient number of droplets managed to penetrate the lowest parts of the plant and there was a less than $50 \%$ reduction in coverage of the lower part in comparison with the upper part. Moreover, impression area of a single droplet and subsequent droplet size were also sufficiently large. This confirmed the hypothesis that air-injector nozzle types ensure better spray deposition on potato plants. These results partially correspond to Klausen's findings (2007) of a better spray deposition with air-injector nozzles in comparison with standard nozzles. Nonetheless, our results are not directly comparable with his findings since his trial involved an air-assisted sprayer and a Danfoil sprayer, while our own included a standard sprayer. The hypothesis was only confirmed for the IDK nozzle, and not the symmetric double flat fan air-injector nozzle TWIN. The coverage value of this nozzle type was insufficient particularly in the lower part of the plant. Despite a sufficient impression area of a single droplet, droplet impression number per $\mathrm{cm}^{2}$ proved to be too small. It is assumed that spray jet angles of the TWIN nozzle $\left(30^{\circ}\right.$ forward angle and $30^{\circ}$ backward angle) are too wide, thus reducing the possibility for the droplets to penetrate the lower parts of the plant. Our findings are different to those of Knewitz and Koch (2010), Kierzek and Wachowiak (2009), and Luckhard and Brune (2011), all determining that the use of air-symmetric double flat fan injector nozzles results in a better coverage in comparison with the single spray jet airinjector nozzles.

Standard ST and TR nozzles reached worse coverage values of the middle and lower part of the plant. Our results on this point are in accordance with Stangl's statement (2009) that nozzles with fine droplets are not able to sufficiently penetrate the thick canopy. Both nozzle types form relatively fine droplets which do not have sufficient velocity and enough kinetic energy to penetrate the thick canopy. Due to this fact, droplets are much more subject to drift. The ST and TR nozzles bear the most pronounced reduction in coverage value, particularly in the middle part of the plant where it dropped to $52 \%$ (ST) and $42 \%$ (TR) in comparison with the upper part value. Similar reduction occurred with the impression area of a single droplet. On the middle part of the plant, the latter decreased by $68 \%$ (ST) and 75\% (TR) in comparison with the upper part value. Our results on this point do not correspond to the results of Gajtkowski et al. (2005), and Stallinga et al. (2010) who determined that, in comparison with airinjector nozzles, the use of standard nozzles results in a better spray deposition on potato plants.

As anticipated, coverage value decreased, from the top towards the lower part of the plant, regardless of the nozzle type. This corresponds to the findings of Stallinga et al. (2010). Contrary to their statements, however, the droplet impression number per $\mathrm{cm}^{2}$ increased. It is assumed that this was caused due to a larger overlap of spray patterns from the adjacent nozzles and finer droplets at a 
larger vertical distance between the nozzle and the middle/lower part of the plant.

Our findings are limited to the fungicide deposition, excluding the research on the biological efficacy of the fungicide in potato late blight (Phytophthora infestans L.) and early blight (Alternaria solani L.) control. Nonetheless, potato late blight and early blight infections did not occur in our trial.

\section{CONCLUSION}

Results of the trial show the flat fan airinjector nozzle IDK achieved the best fungicide coverage of potato leaves in the upper, middle and lower part of the plant. This nozzle reached the highest spray mixture coverage value while retaining a sufficient impression area of a single droplet in the middle and lower part of the plant. Furthermore, the coverage with spray mixture applied by the nozzle dropped by $28 \%$ in the middle part of the plant and by $46 \%$ in the lower part, which is less than with other nozzle types. The IDK nozzle forms a single vertical spray jet of coarse droplets with enough velocity and kinetic energy for the droplets to penetrate the thick canopy. Results show that the angles of both spray jets of symmetric double flat fan air-injector nozzle TWIN (the $30^{\circ}$ forward and the $30^{\circ}$ backward angle) are excessively wide in order for the droplets to penetrate all the way to the lower parts of the plant. This nozzle did thus not confirm the proposed hypothesis. The use of both standard nozzle types resulted in a worse coverage and impression area of a single droplet despite them having the largest droplet impression number per $\mathrm{cm}^{2}$. The two standard nozzles form a larger number of fine and very fine droplets which are excessively light and do not have enough speed to penetrate all the way to the lower parts of the plant. Among these droplets, there is a large percentage of driftable droplets $(<150 \mu \mathrm{m})$ which are extremely sensitive to drift.

Our conclusions refer to annual results. In order to confirm results as a whole, additional field trials should be performed in the years to come. Further research should involve biological efficacy of fungicides according to various nozzle types. This would give us an even clearer picture on the effect of various nozzle types and subsequent spray deposition quality on the efficacy of potato late blight (Phytophthora infestans) and early blight (Alternaria solani) control.

\section{REFERENCES}

Agrotop, 2010. Albuz AVI-TWIN. [online] URL: http://www.agrotop.com/attachments/article/106/211 7.pdf

Brune, R.A. 2011. Wasermenge perfekt abstimmen. DLZ Agrarmagazin 4: 82-85.

Gajtkowski, A., Bzdega, W., Migdalska, P. 2005. Spray coverage in potatoes with low drift and airinduction nozzles. Journal of Plant Protection Research, 45, 1: 17-23.

Hadživuković, S. 1991. Statistički metodi. Novi Sad, Inštitut za ekonomiko poljoprivrede i sociologiju sela: 585 p.
Kierzek, R. 2007. New solutions in the technology of protecting potatoes from diseases. Ochrona Roślin, 52, 12: $26-29$.

Kierzek, R., Wachowiak, M. 2007. Effect of new spray equipments on the leaf coverage of potato. Progress in Plant Protection, 47, 1: 150-154.

Kierzek, R., Wachowiak, M. 2009. Effect of new spray nozzles on potato leaf coverage with working liquid. Progress in Plant Protection, 49, 3: 11451149.

Klausen, N.E. 2007. Spraying technique in potato. [online]

URL: 
http://www.danfoil.dk/pictures_org/Farm\%20Test.p df

Košmelj, K. 2001. Statistične metode. Delovno gradivo 2000/2001. Ljubljana, Biotehniška fakulteta: 90 p.

Knewitz, H., Koch, H. 2010. Was die neuen Düsen bringen? DLG-Mitteilungen, 3: 68-71.

Kryger Jensen, P. 2007. Can new spray techniques improve control of potato late blight? Status and future possibilities. [online] URL: http://130.226.173.223/lbnordic/PPT/930_950_Pete r_Kryger.pdf/

Lešnik, M. 2007. Tehnika in ekologija zatiranja plevelov. Ljubljana, Kmečki glas: 243 p.

Luckhard, J., Brune, R. 2011. Kartoffel rundum schützen. Kartoffelbau 4: 18-23.
Spray application technique, 2003. British potato council. [online] URL: http://www.potato.org.uk/media_files/FAB_GAs/6s pray_technique2004.pdf

Stallinga, H., van de Zande, J.C., Michielsen, J.M.G.P., Meier, R., Schepers, H.T.A.M., van Velde, P., Verwijs, B. 2010. Effect of sprayer speed and nozzle type on spray distribution and biological efficacy in potato late blight control. Aspects of Applied Biology, 99: 89-96.

Stangl, J. 2009. Applikationstechnik - Wie viel Wasser und welche Düse? Die fortschrichttliche Landwirt, 19: 27-29.

Strasburger, E. 1991. Lehrbuch der Botanik für Hochschulen. Stuttgart, Jena, New York, Gustav Fischer Verlag: 1030 p. 